\section{Kaunas of 1919-1939: a temporary capital built by its citizens}

INSTITUTE OF ARCHITECTURE AND CONSTRUCTION

OF KAUNAS UNIVERSITY OF TECHNOLOGY

\section{INTRODUCTION}

Upon embarking on exploration of

Lithuanian modernism, it is important to

take a short glimpse at the political envi-

ronment. Just after the end of World War

Lithuania, along with the other Baltic

countries, became independent. However, soon after this, in 1919, the historical capital, Vilnius was lost, and the government of the Republic of Lithuania had to move to Kaunas - the second largest city in the country. This previously military town of Tsarist Russia became the temporary capital of the country until 1939. During a shor but very intense period, Kaunas lived through one of the most important phases

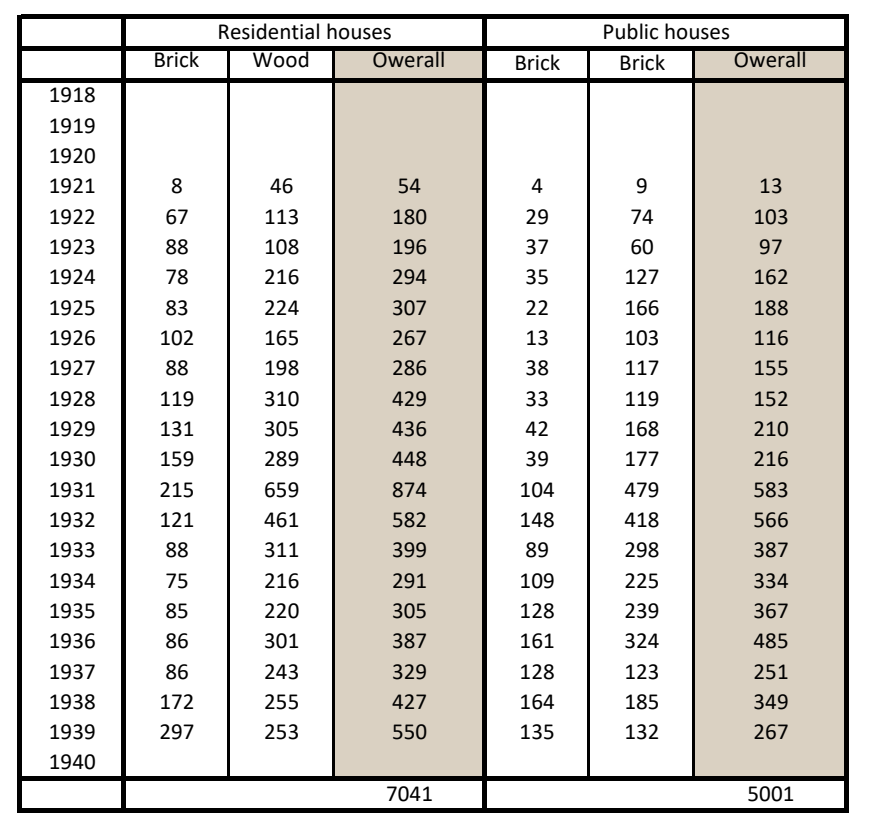
development. Its a huge constuction bonoked ing to create the entire necessary infrastructure: governsary in rastructure. governeducational institutions (a un versity, academies and schools), business offices, hotels, industrial facilities, housing, and genera infrastructure of the city (pipelines, sewerage, a new transportation system, roads and parks). During a few decades of independence, Kaunas produced an entire architectural layer and experienced a large-scale modernization of the city.

Unique spirit of that period has largely contributed to sustaining the aura of freedom and strong identity during the Soviet period. As a conseguence, the process of acceptance of this

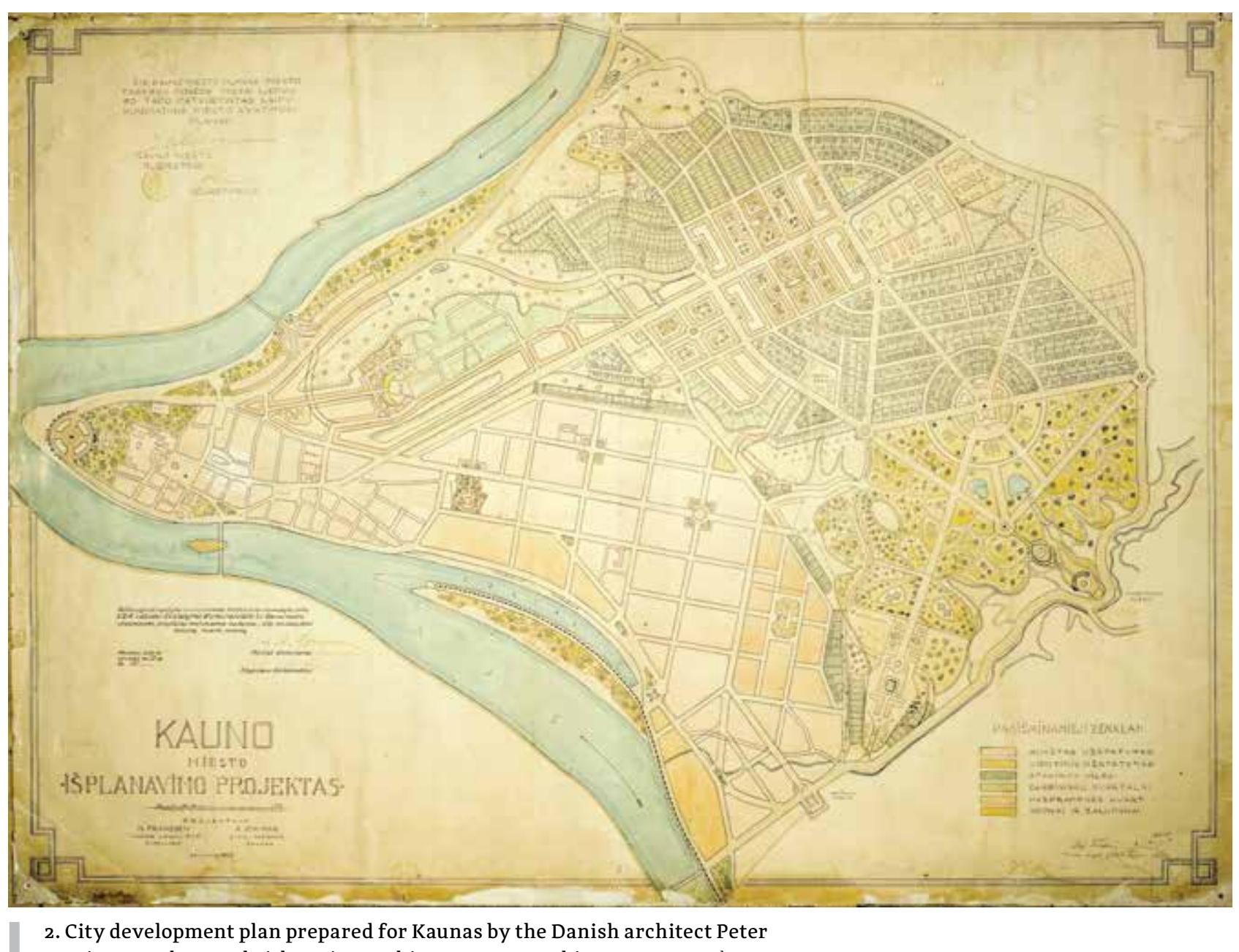

2. City development plan prepared for Kaunas by the Danish architect Peter implemented. LCVA

legacy as a cultural heritage has a surprisingly long history. Some of the buildings were recognised as architectural monuments of local significance as early as in 1972 and thus are examples of one of the arliest inscriptions of modern architecture into a cultural heritage list.

Recent decade continues to appreciate this layer of the city as an important aspect of the city's identity and representation. On 15 April 2015, Brussels conferred " Kaunas as a test. of the temporary Lithuanian's capital's nomenon. That same year Kaunas was awarded the title of UNESCO Creative City of Design, with the inter-war heritage acknowledged as a principal criterion for the designation. The architectural legacy was also mentioned in Kaunas' successful bid to be named the European Capital of Culture for 2022. The cultural agenda for that year will include a programme entitled

"Modernism for the Future", interpreting the inter-war heritage within a broader artistic, social and cultural context. In 2017, Kaunas' modernist architecture was included in the tentative list of UNESCO world heritage sites.

TRANSFORMATION PROCESS AND

THE CHARACTER OF THE CITY

Perhaps the most important thing about Kaunas architecture between World War I and World War II is the extent and pace of the transformation process. During the interwar period in less than 20 years more than 12,000 buildings have been prebuilt. They are still standing in today's pared (fig. 1) and more than 6,00o have been 

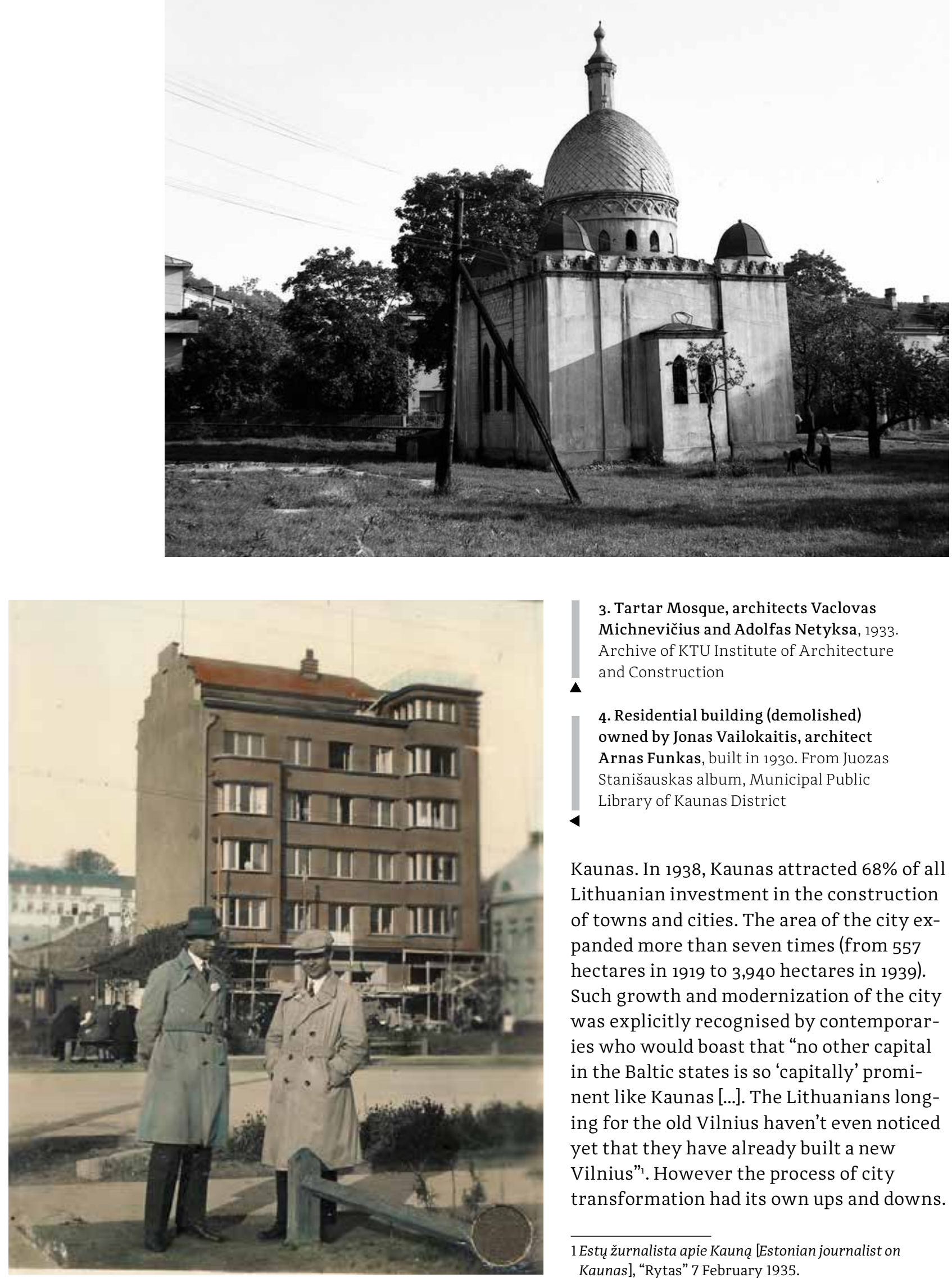
Archive of KTU Institute of Architecture and Construction

4. Residential building (demolished) Aned by Jonas Vailokaitis, architect Arnas Funkas, built in 1930. From juoz Library of Kaunas District

Kaunas. In 1938 , Kaunas attracted $68 \%$ of all Lithuanian investment in the construction 作 towns and cities. The area of the city expanded more than seven times (from 557 hectares in 1919 to 3,940 hectares in 1939). such growth and modernization of the city was explicitly recognised by contemporaries who would boast that "no other capital in the Baltic states is so "capitally' prominent like Kaunas [...]. The Lithuanians longing for the old Vilnius haven't even noticed yet that they have already built a new Vilnius". However the process of city transformation had its own ups and downs.

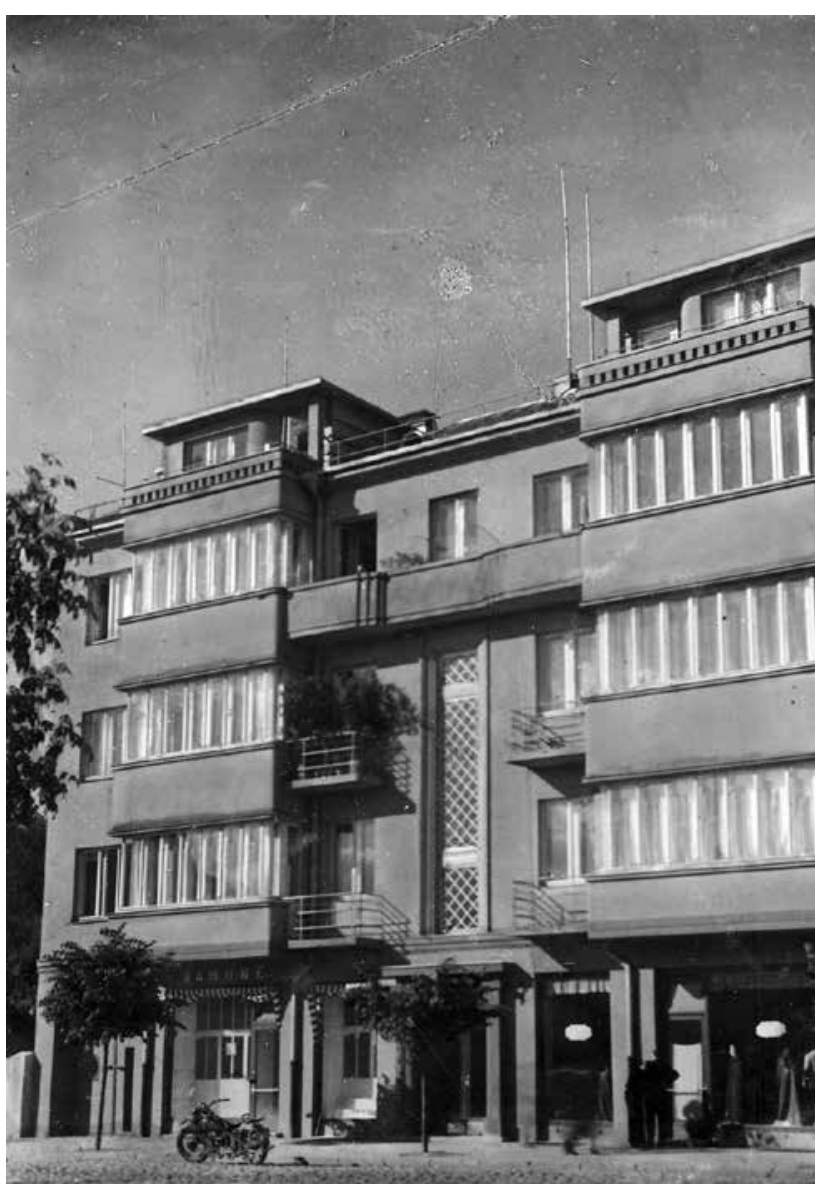

5. A residential building owned by Juozas Daugirdas, Juch Kaunas District

The first years of independence were difficult for Kaunas and the country as whole. One municipal activist, Jonas Kriači Onas, not the lack of pablic Kriaucinas, warder in post-World War Kaunas. "Abandoned government-owned wooden shacks were ransacked and dismantled by hungry and cold inhabitants. Doors and windows were broken and ripped out, stoves were dismantled and flooring was torn up". The construction sector also languished. An uptick in construction activity only became evident in 1922. Between the years 1918 and 1921, only eight brick and forty-six wooden ho fory-six woded in Kaunas, but in tion and one hundre thirteen for wooden structures.

2 J. Kriaučiunnas, Kai įsiküré Kauno miesto savivaldybè [When the municipality of Kaunas was established]

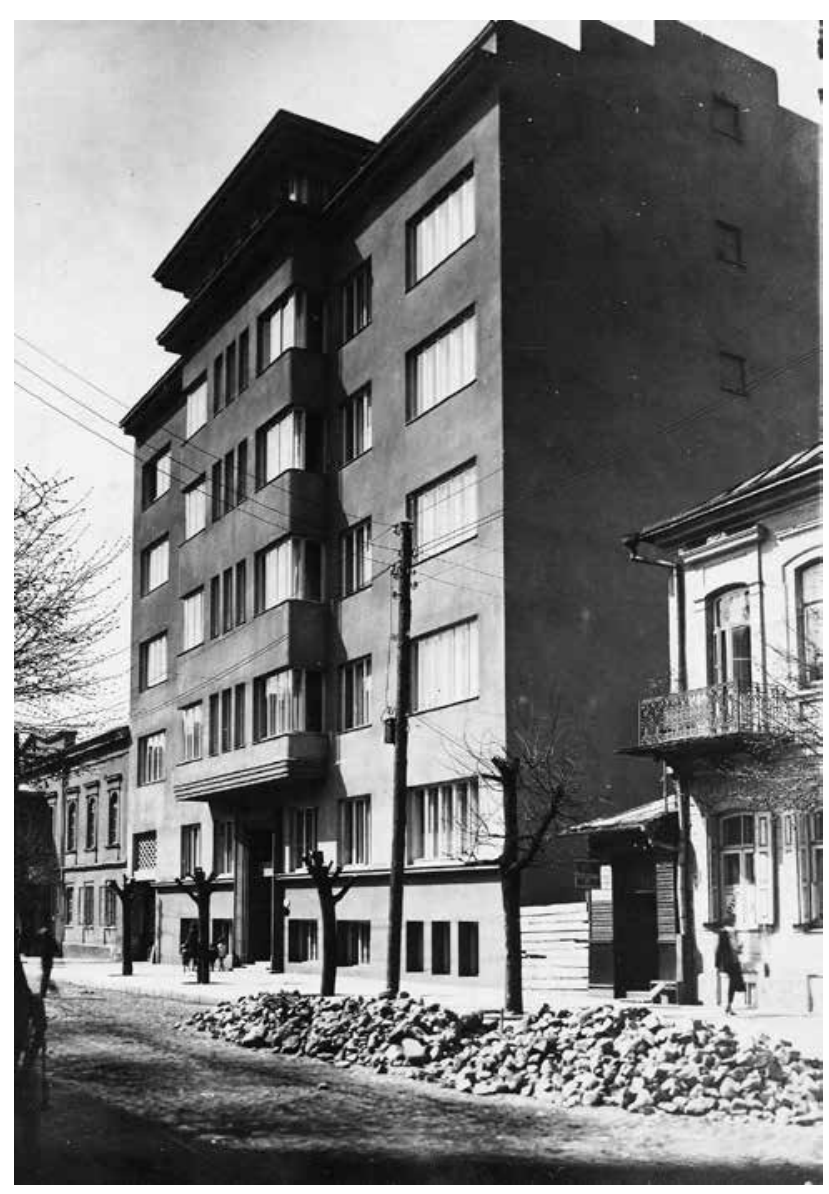

6. House built by Chaimsunai family, architect Vytautas Landsbergis-Žemkalnis, built in 1931. Photo by G. Česonis, 2016

In 1923 Danish architect Peter Marius Fandsen and Lithuanian architect Antanas Jokimas (fis. 2) prepared a city development plan However, actual development of the city was rather different from the ideas of Franden. Most of the construction was carried out not in separate newly-designed quarters, but based on the existing grid. The new buildings were embedded in the already existing urban structure. However, it should be noted that even in the late 1930s only a small part of the plan - the living area of Žaliakalnis - was implemented. Meanwhile, the city continued to evolve by extending the existing urban framerk premises, many offices and residents had to remain in Tsarist-era buildings, which were renovated and expanded, and which gradually increased in height. 


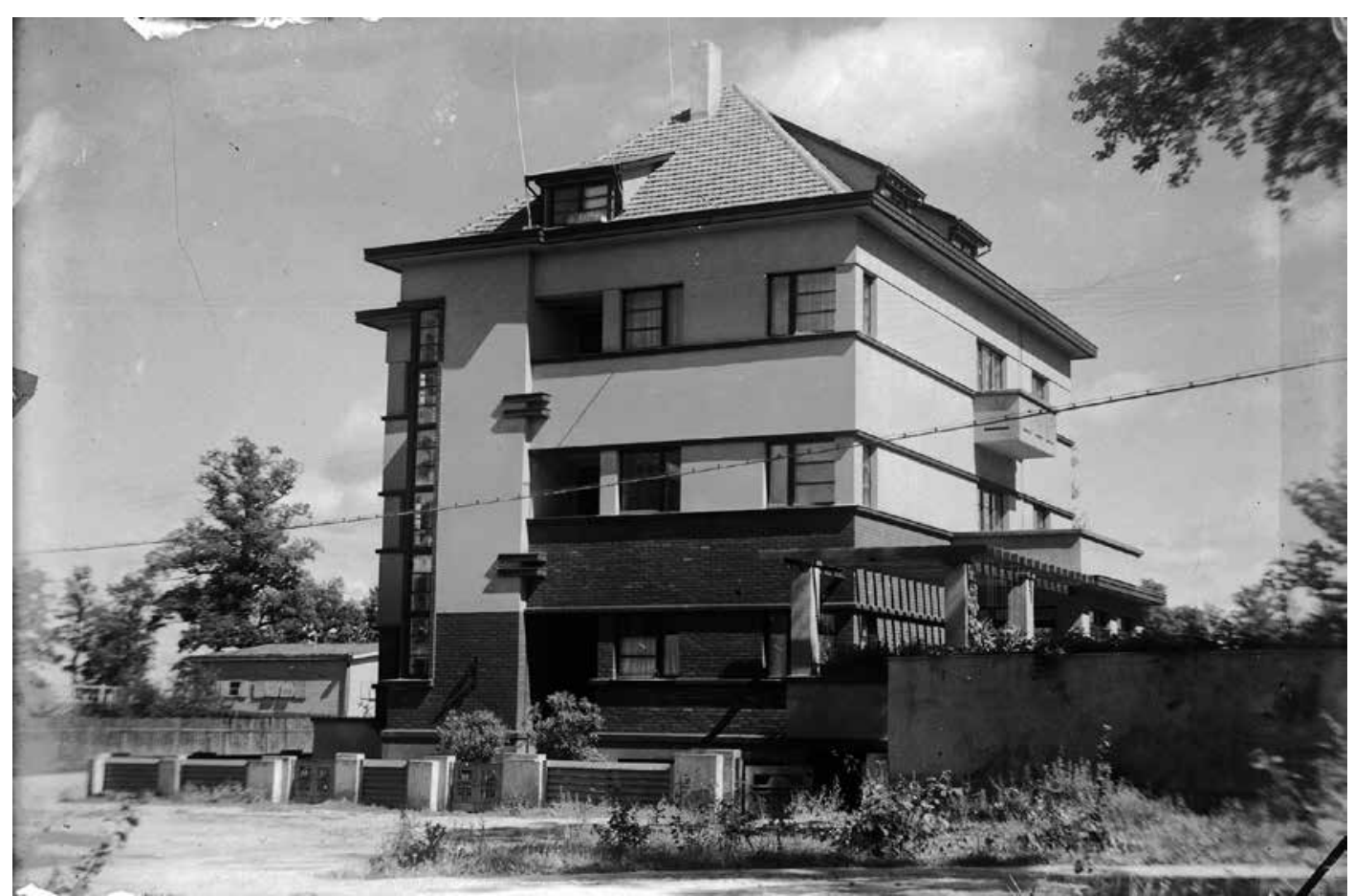

7. House for Baronai and Visockiai families, architect Bronius Elsbergas, built

- in 1933. M. K. Čiurlionis National Art Museum Archives

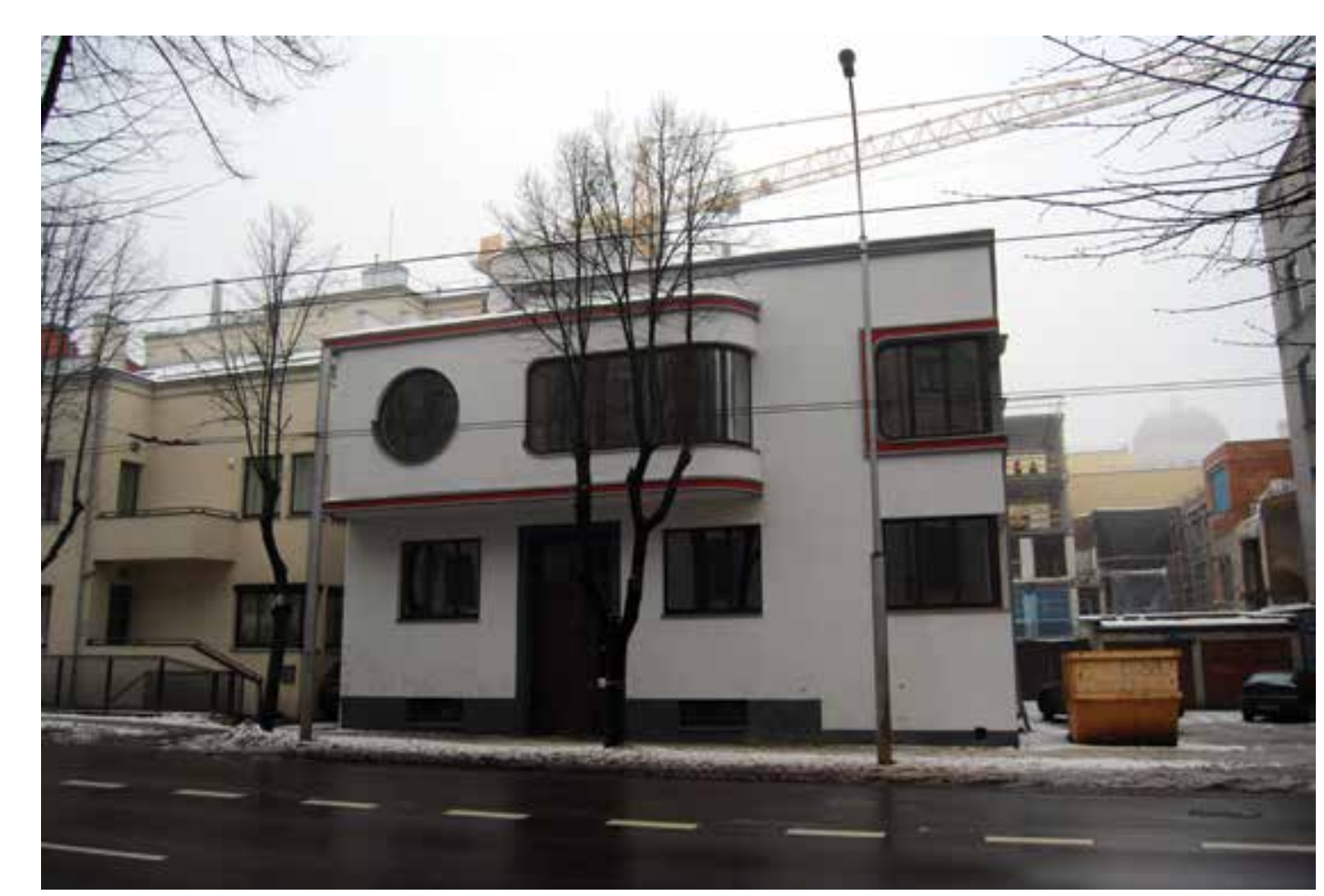

8. House for Iljinai family, architect Arnas Funkas, built in 1934. Photo
by V. Petrulis, 2017

9. Office building of "Pienocentras" company, built in 1932, architect Vytautas Landsbergis-Žemkalnis. LCVA, photodocuments department

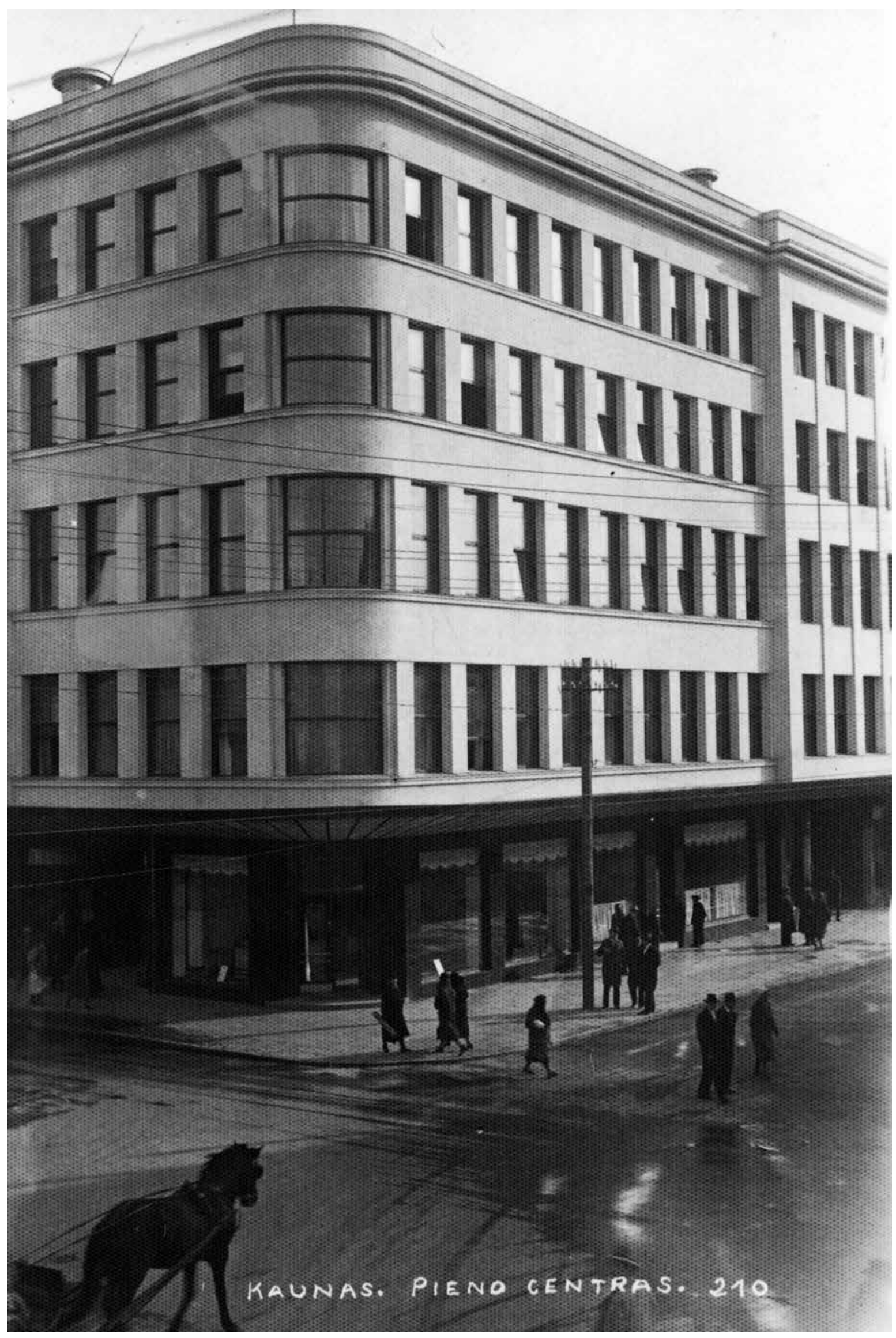




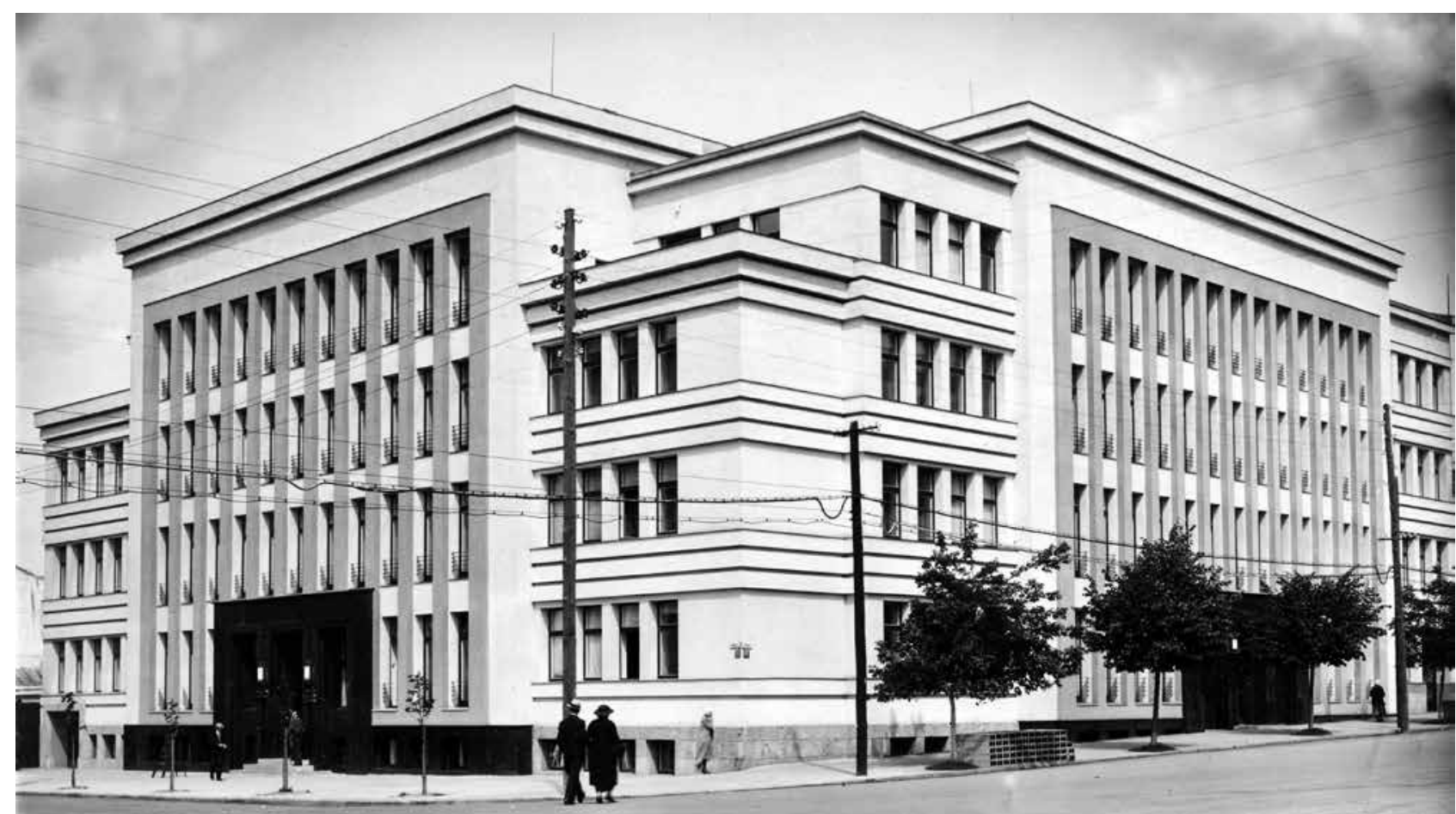

10. Kaunas County office and Lithuanian State Security Department, architect Vytautas

10. Kaunas County office and Lithuanian State Security Department, arch
Landsbergis-Žemkalnis, built in 1933. LCVA, photodocuments department

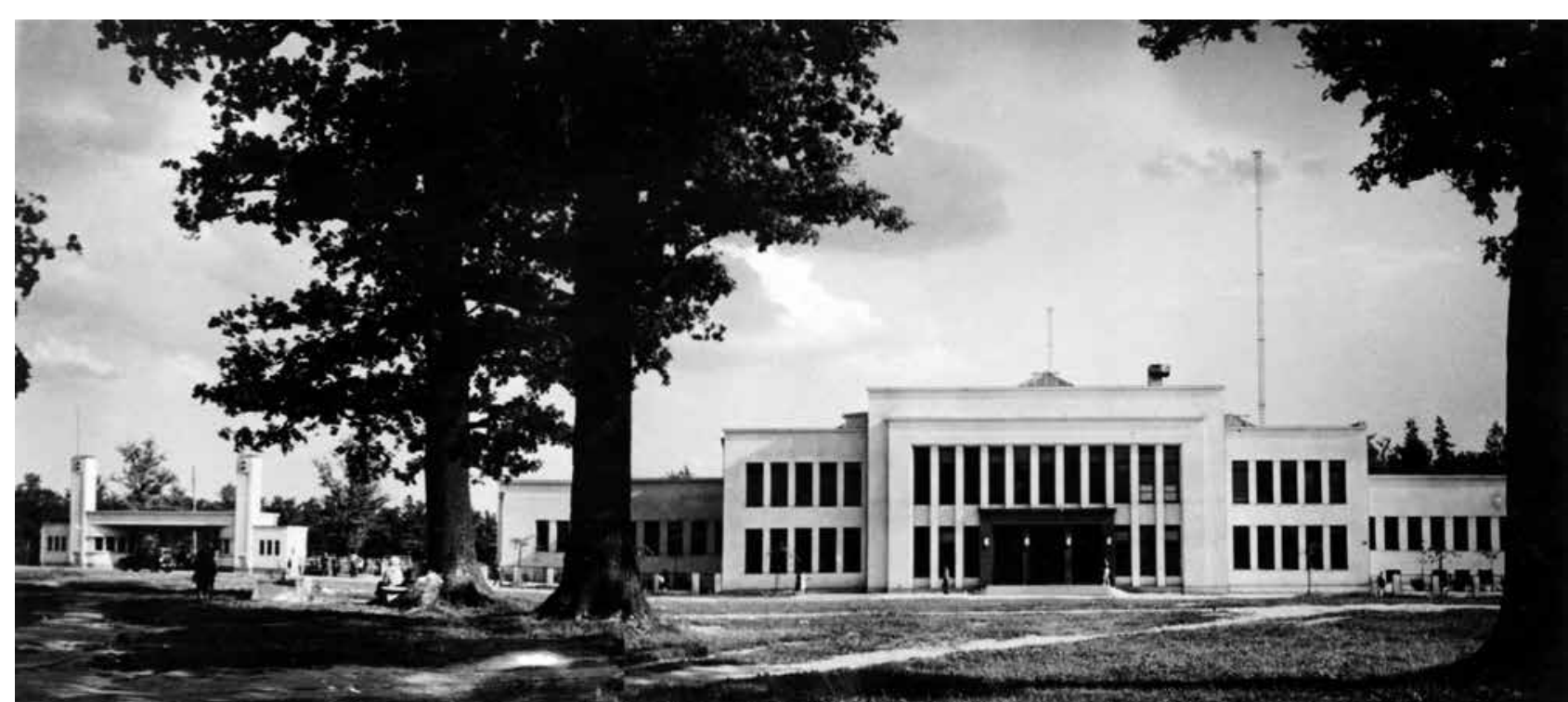

11. Palace of Physical Culture, architect Vytautas Landsbergis-žemkalnis, built in 1934, LCVA,

photodocuments department

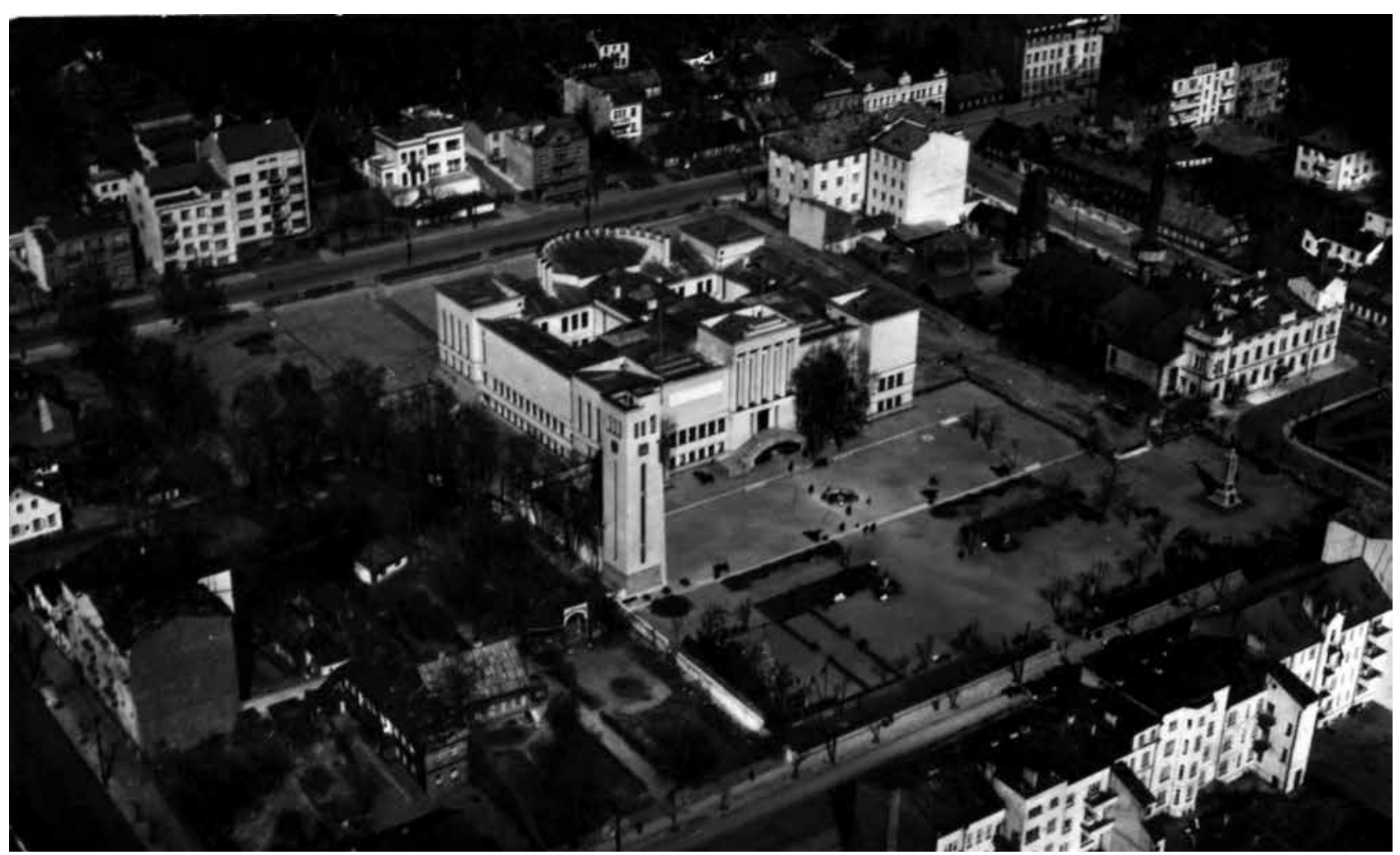

12. Vytautas the Great War Museum, architects Kazimieras Kriš̌̌čukaitis, built in 1936 From personal collection of Antanas Burkus

13. Chamber of Commerce, Industry and Crafts, architect Vytautas LandsbergisZational Art Museum Archives

The shortage of living space was particularly evident on the rental market. A situation was only made worse by the appropriation of existing residential building for use of the military and government institutions. According to eye witnesses from the period, many people dreamed of simply having a small apartment or room in Kaunas. This early period, popularly known Kaunas. This early period, popularly known as the "apartment crisis", became a true golden era for architects and contractor buildings constructed in the city centre brought profits of up to twenty-five percent. Such returns on investment and high demand from prospective tenants helped spur further construction development.

However, the construction boom had 

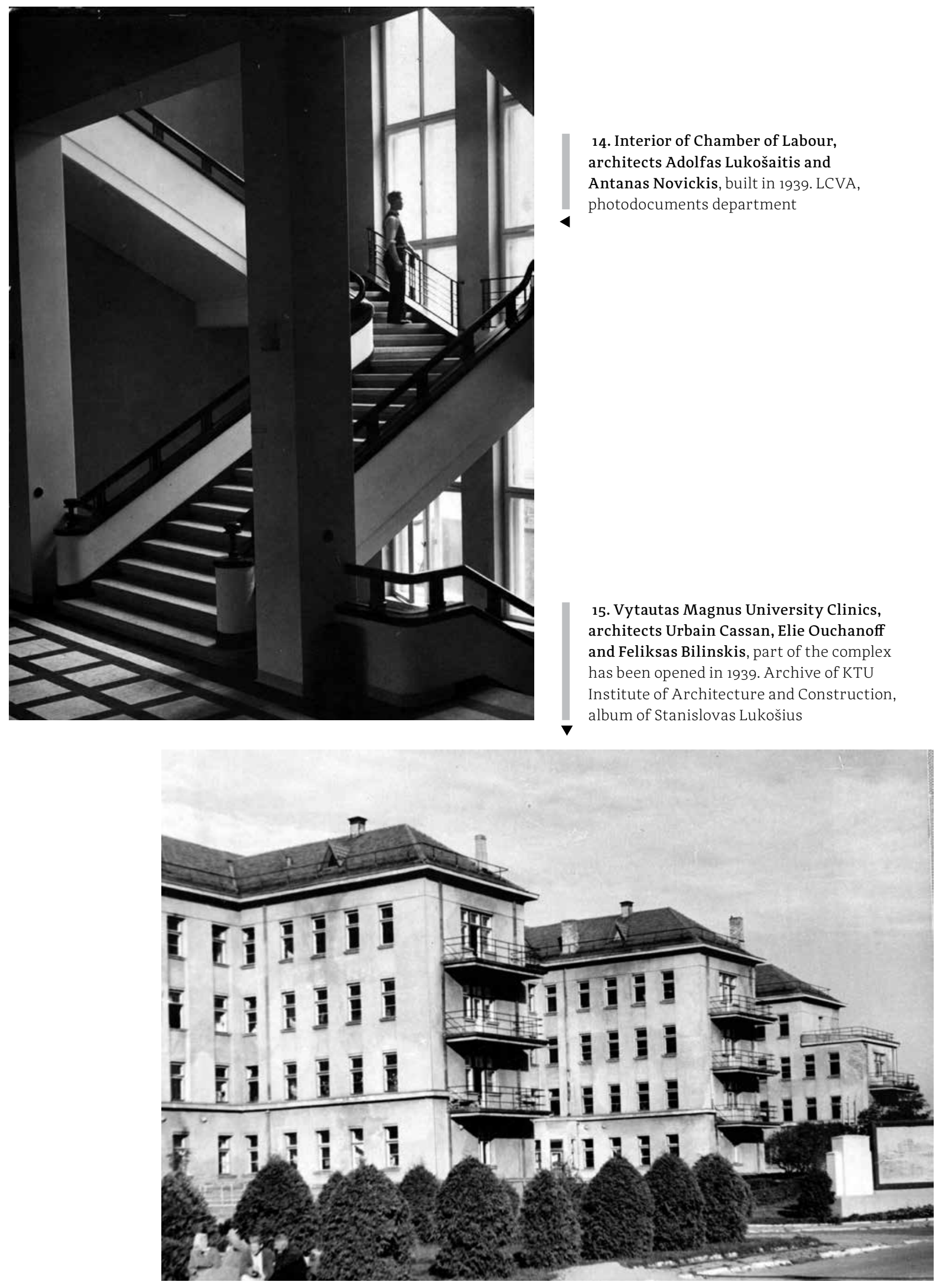

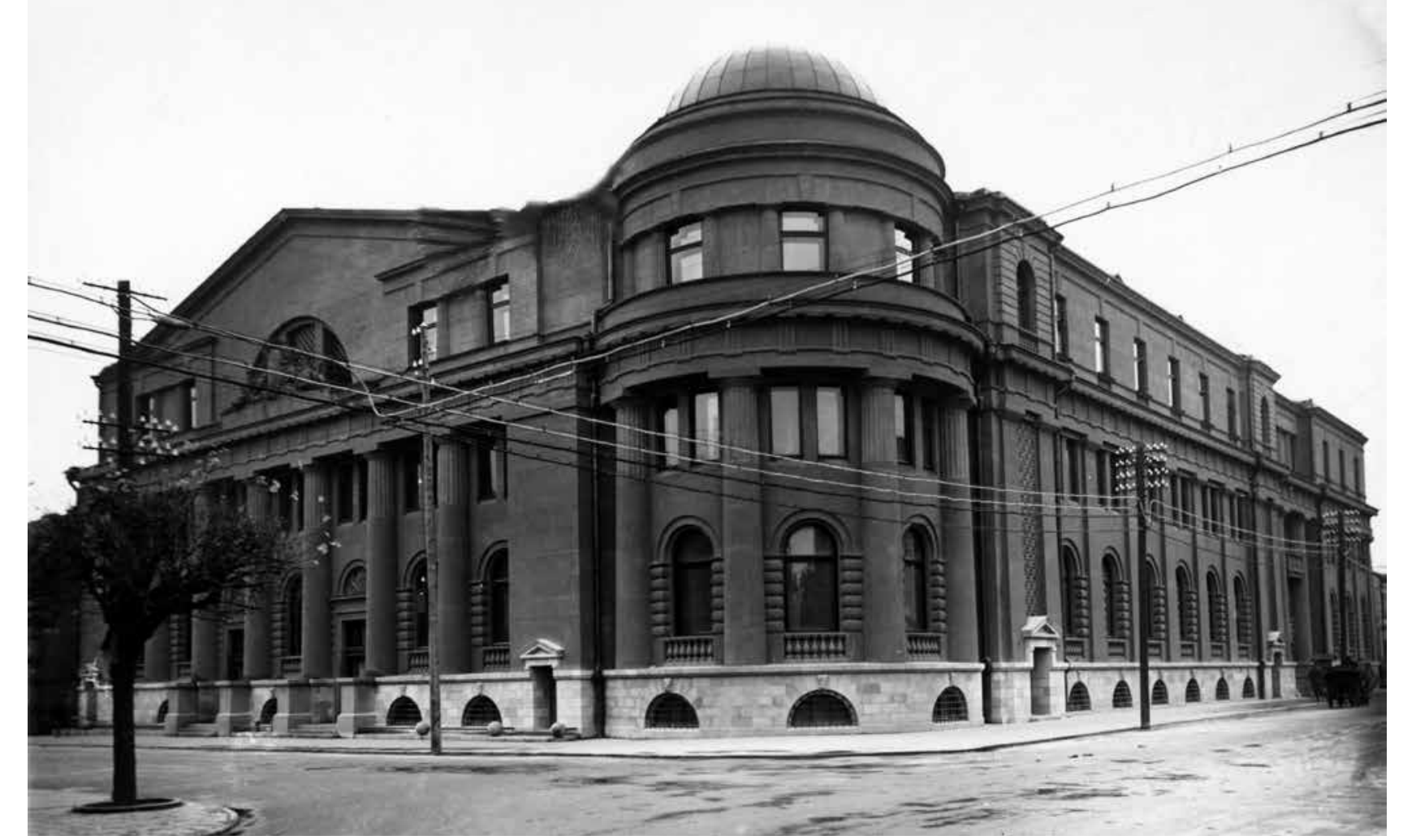

16. Bank of Lithuania, architect Mykolas Songaila, built in 1929. LCVA, - photodocuments department

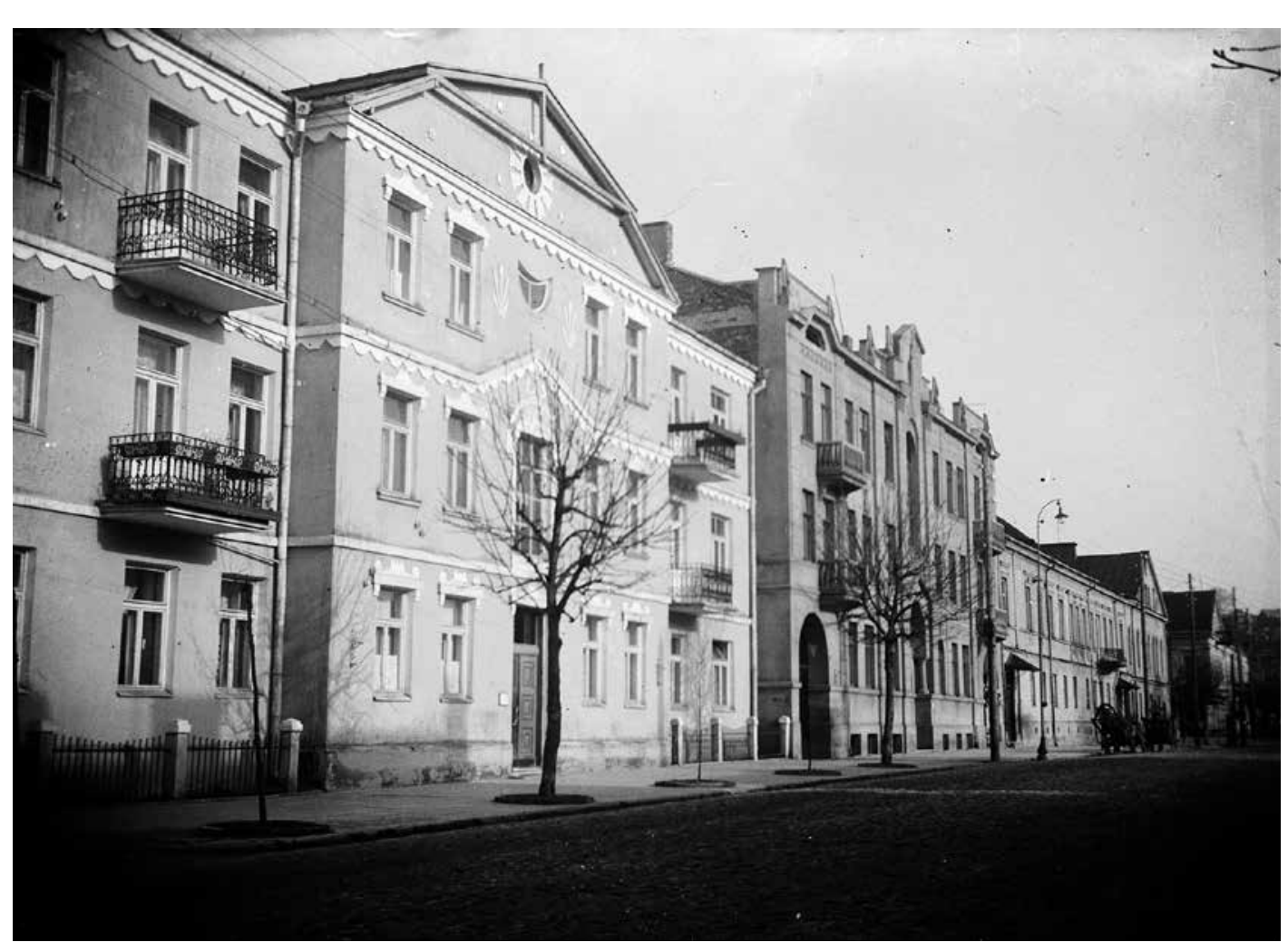

17. Tulpé Cooperative apartment building, architect Antanas Maciejauskas,

- built in 1926, M. K. Čiurlionis National Art Museum Archives 


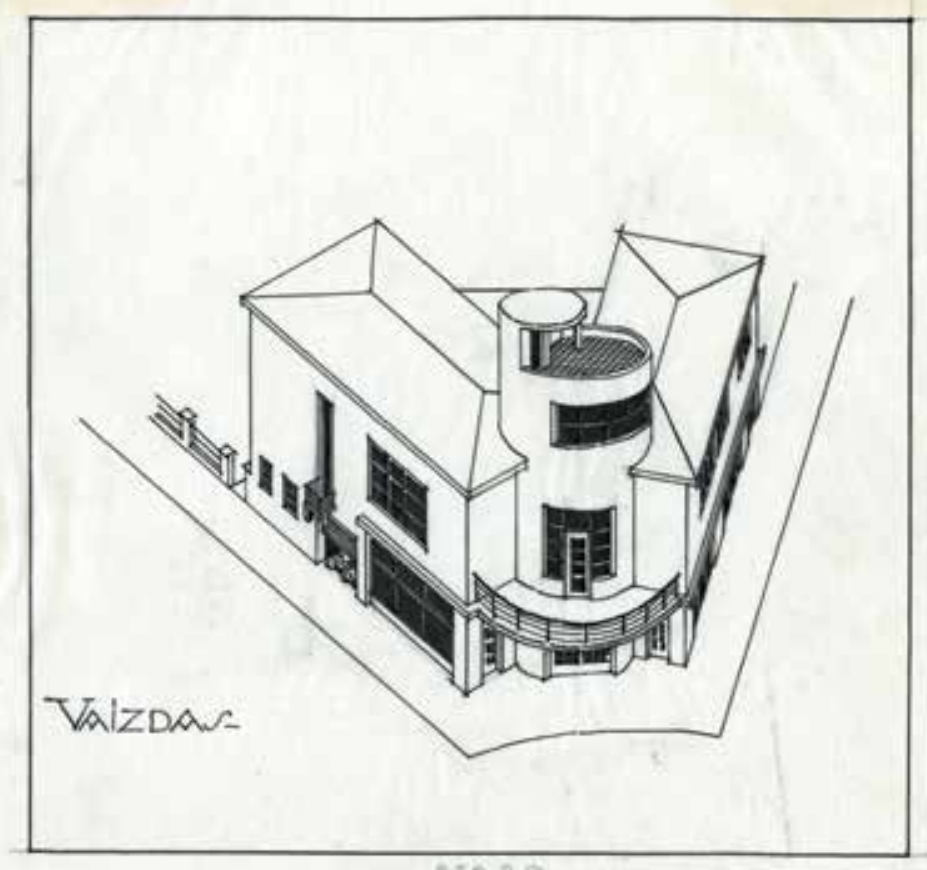
18. A design proposal for the home of Adelè ir Paulius Galaunès (never
implemented), architect Vladimiras Dubeneckis, 1930. M. K. Čiurlionis implemented), architect Vladim
National Art Museum Archives its darker side as well. A residential market distorted by the shortage of housing led to hasty construction and a disregard for quality. Many buildings were completed without permits or approved plans. As noted in 1933 by Kaunas' leading municipal noineer, Karolis Reisonas, as many as nety Karolis Reisonas, as many as ninety percen of homes constructed in this period deviated from their proposed designs ${ }^{3}$. There was also a shortage of experienced construction specialists, contractors and craftsmen. Nevertheless, the situation stabilized within a few years. New keywords such as spacious, clean, bright and efficient took hold in the Lithuanian public and architectural the Lithuanian public and architect

\section{(}

3 Kauno statybai trüksta saiko sako K. Reisonas [Kaunas "Dienos naujienos" 9 January 1933.

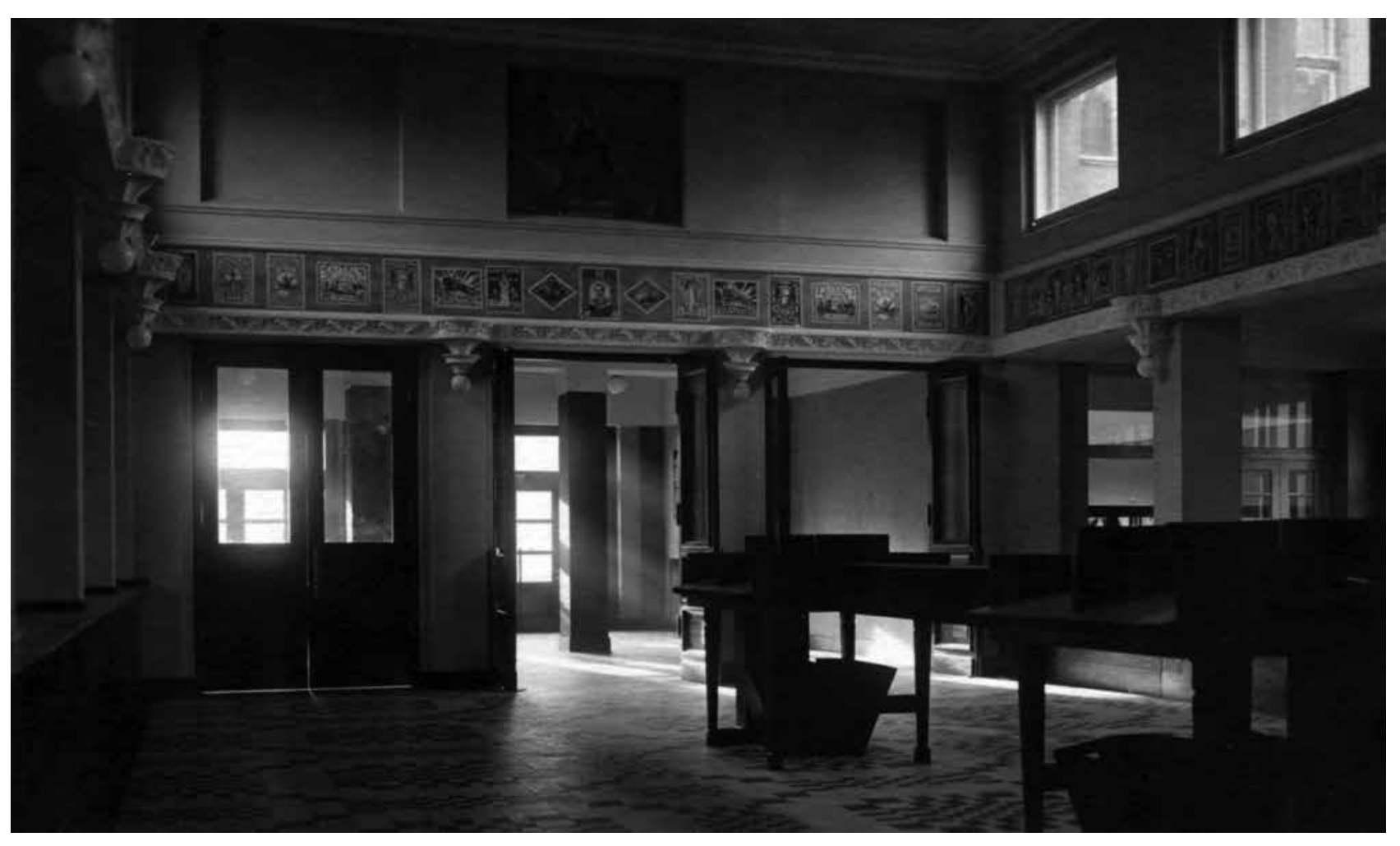

19. Interior of Kaunas central post office, architect Feliksas Vizbaras, - built in 1931. From personal collection of Antanas Burkus

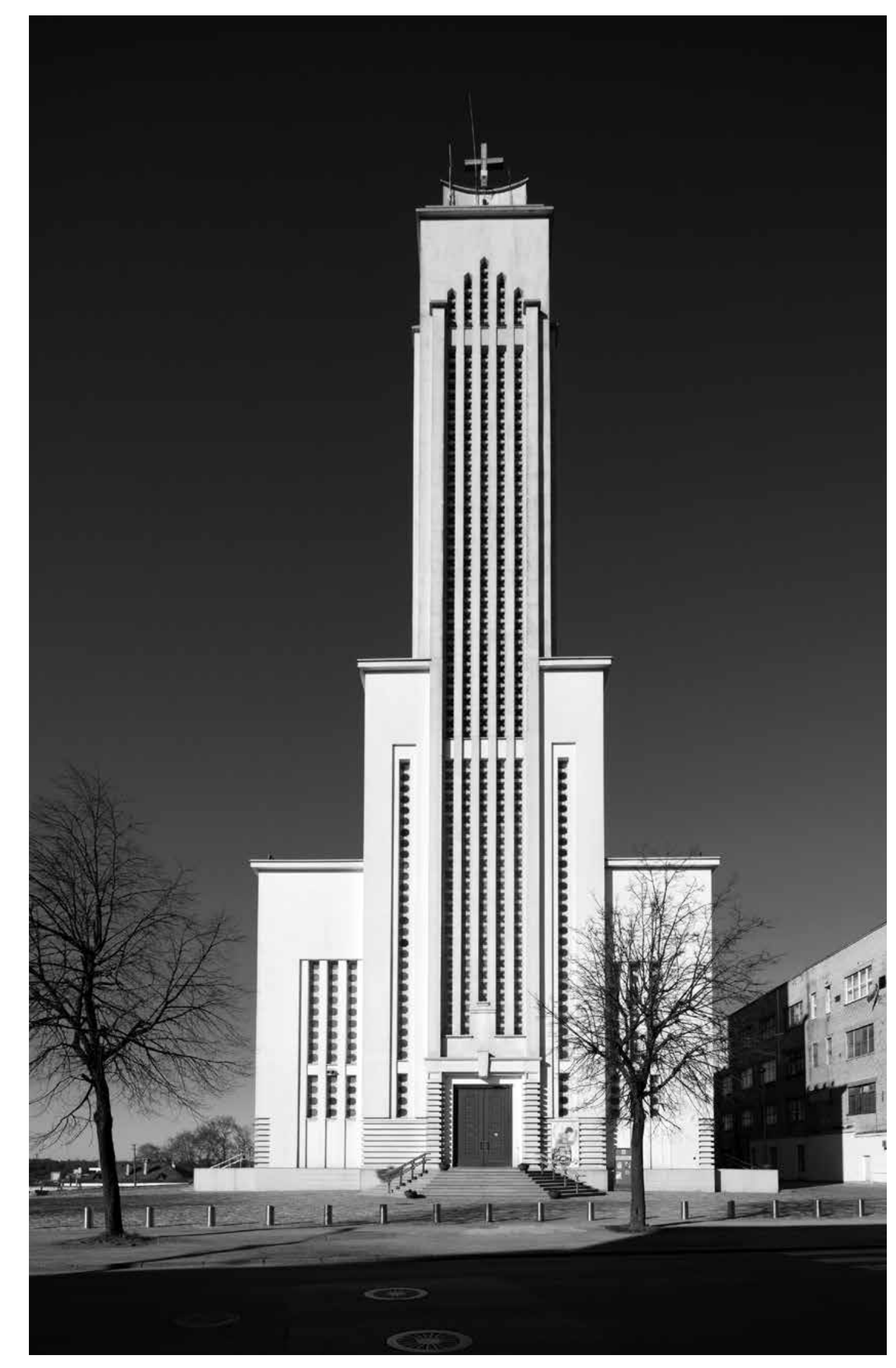

20. Christ's Resurrection Church, architect Karolis Reisonas, - built from 1931. Photo by G. Česonis, 2018 
prevailing international understanding of modernism and helping to define the quality standards expected from new buildings. Architectural processes of early years reflect another important aspect of Kaunas at that time - ethnical diversity. First census of population showed that in 1923 Kaunas had 92446 inhabitants with 59 \% Lithuanian, 27 \% Jewish, 4,5 \% Polish, 3, $\%$ German and $3 \%$ Russian population ${ }^{4}$ Therefore the architectural landscape of multicultural Kaunas was enriched by the buildings of various ethnic communities, such as refieg

4. Janauskas, Kauno miesto gyventoju tautini sudetis XXa trecioje desimtmecio pirmoje pusije [The Ethnic Composition of Kaunas inhabitants at the beginning of the 1920 's], in: Kauno istorijos metraštis, Kaunas 2015 , p. 209-218, 211 .

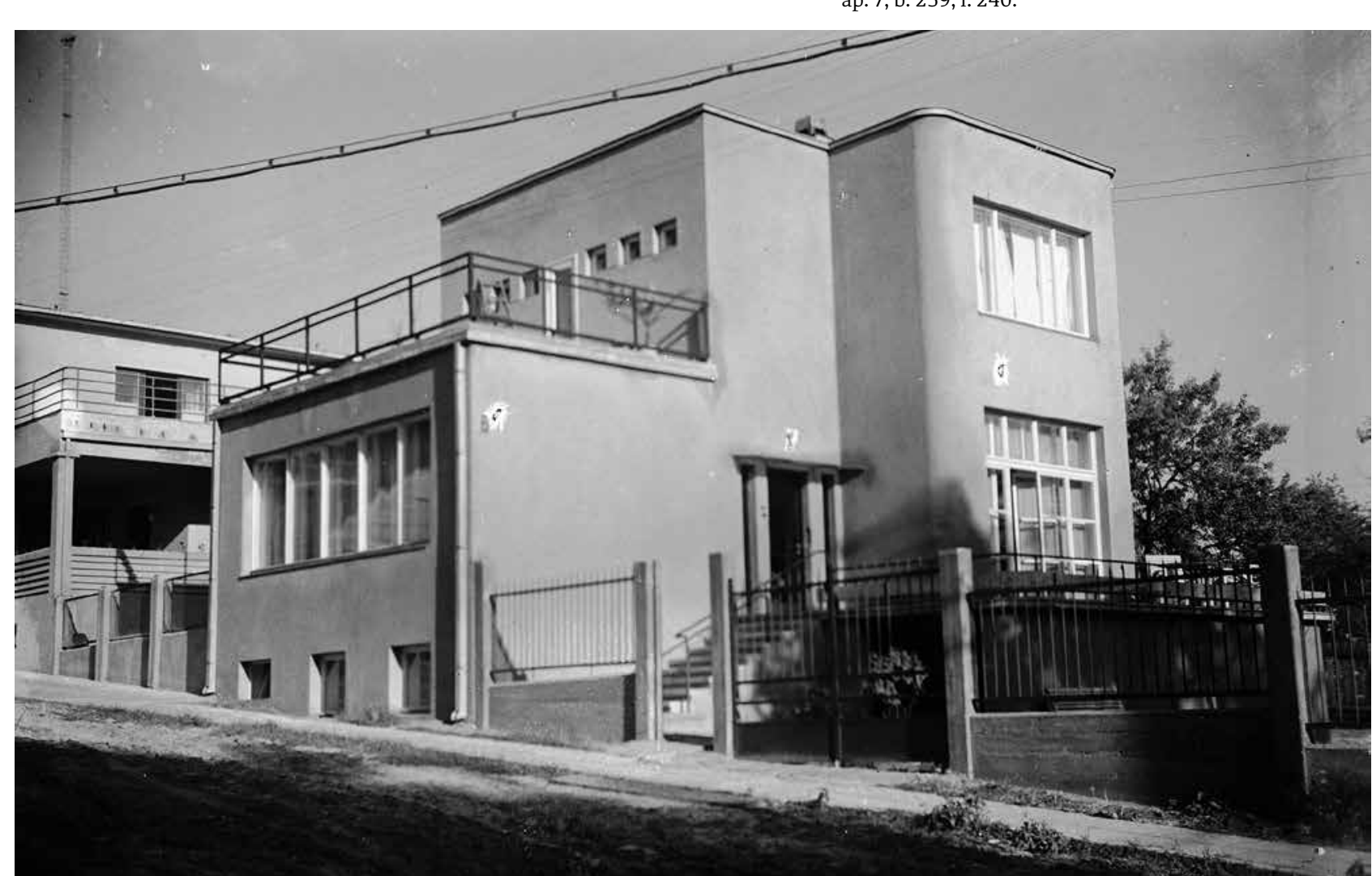

21. Home of Glemžai family, architect Jokūbas Peras, built in 1936.

- M. K. Čiurlionis National Art Museum Archive

schools, with distinctive forms of expression (fig. 3). In the multicultural plane of Kaunas it is also important to note the role f engineers, architects, construction technicians and contractors, who have left distinct mark on the architecture of the city. The first organization which was in harge of architectural developments ithuanian Reconstruction Commissaria [Lietuvos atstatymo komisariatas] was very diverse in terms of nationalities. In 1921 there were 13 Lithuanians, 5 Jews, 4 Poles, 3 Swedes, 2 Germans and 1 Latvians employed in the Commissariat's. Later a number of architects and engineers of Jewish,

5 Lietuvos atstatymo komisariate ir komisariato žinioje esanciu tarnautoju sarasasas List of servicemen in the Lithuanian Reconstruction Commissariat], $1921 \mathrm{~m}$. p. 7. b. $259,1.240$.

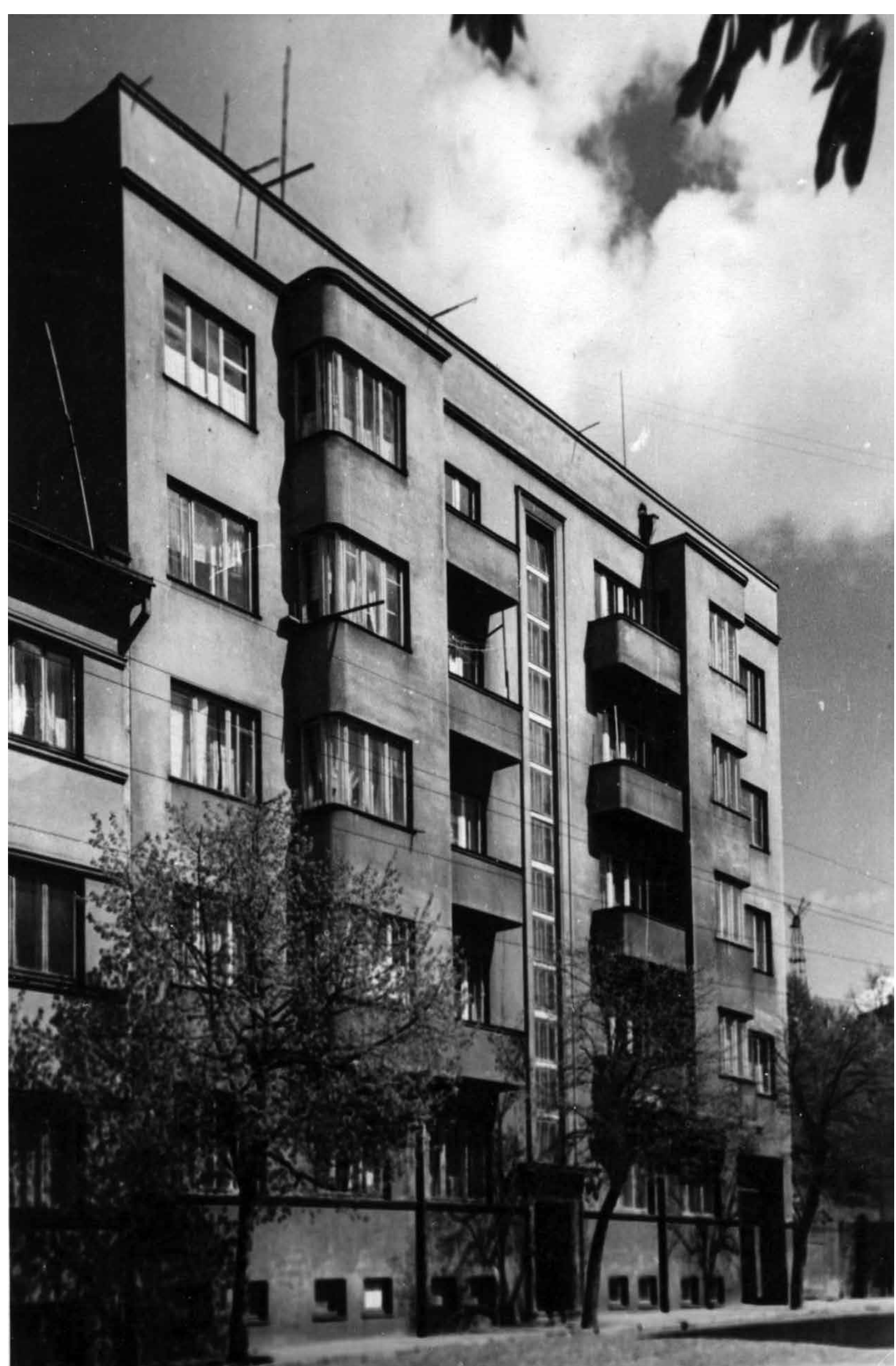

22. House for cooperative Butas [the Apartment], architect Jonas Kriščiukaitis, built in 1932. - Archive of KTU Institute of Architecture and Construction, album of Stanislovas Lukošius 


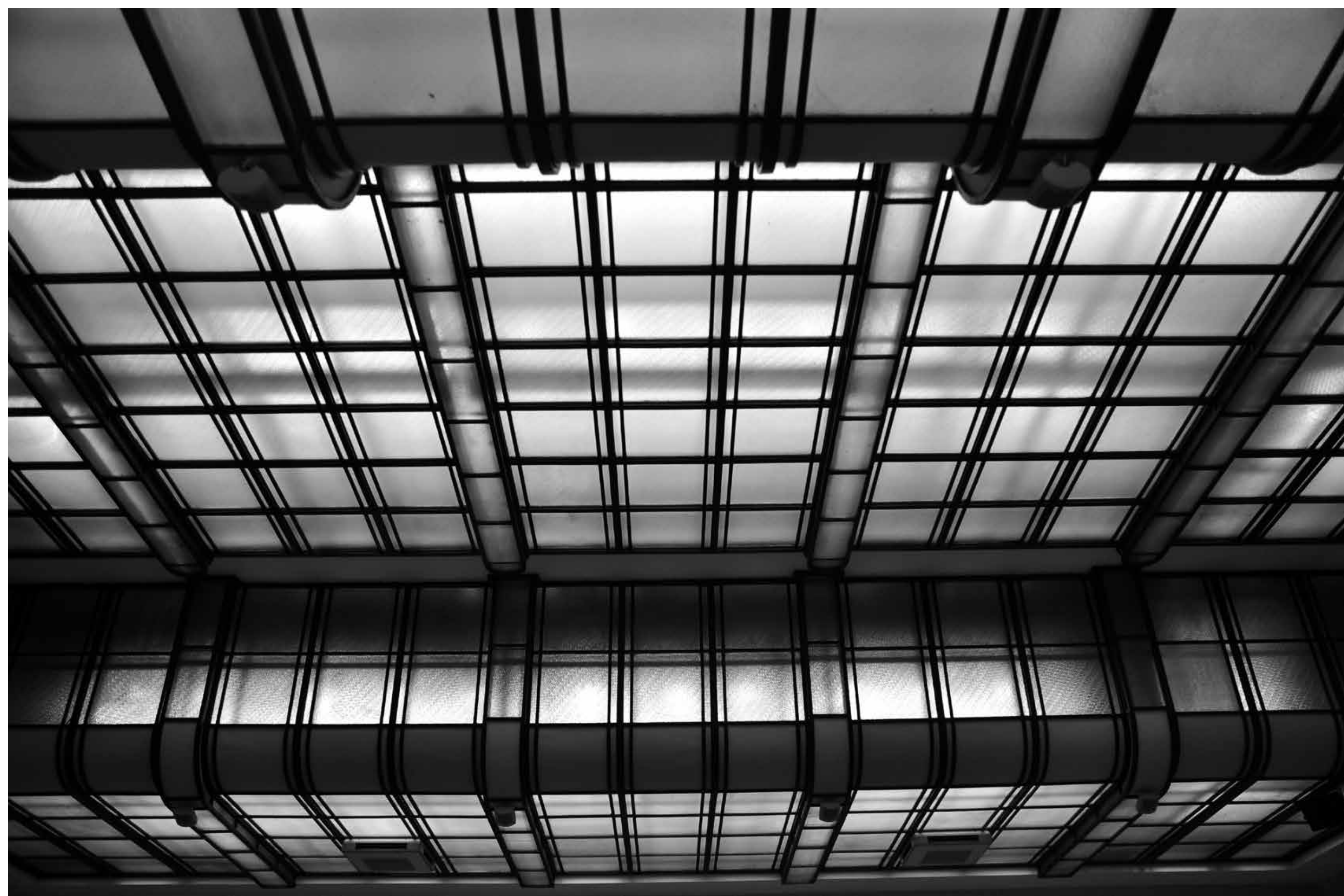

23. Ceiling in State Savings Bank (now Kaunas City Municipality),

architect Arnas Funkas, built in 1940. Photo by V. Petrulis, 2012
Russian, German and other origins enriched the overall context of the interwar modernist architecture in Kaunas.

First important steps towards modernization of the city included introduction of a centralized water supply and sanitation system in Kaunas, the construction of which first begun in 1929. Connecting homes to a city-wide communications system was no only technologically significant, but also symbolized Kaunas becoming a modern and clean city, meeting the standards of civilized European countries. These expectations were embodied first and foremost, by public buildings andluxurious multi-story residentildings and hxurous midester houses that altered the city's urban landscape: the six-storey residence of industrialist and financier Jonas Vailokaitis (complete in 1929, fig. 4), the residential building of Juozas Daugirdas, director of the Drobe corporation (completed in 1930, fig. 5), the seven-storey home of businessmen Mozé and Malka Chaimsonas (completed in 1931, fig .6 or the cooperative Butas [the Apartmi. or the cooperative Butas [the Apartment], a multi-unit building completed in 1932. All of these structures set abenchmark for modern construction in Kaunas - a standard that prevailed until the outbreak of World War II. The global economic crisis reached Lithuania in 1932, considerably impacting building development. Within three years, the scope of construction in Kaunas had fallen almost three times below pre-crisis levels. In 1931, for example plans called for the construction of 874 buildings. By 1934 the construction of 874 buildings. By 1934, however, constiuction bad declined to just 291 buildings. On the other hand, the housing shortage was no longer as acute, and after a salary cut for state employees was implemented, rented flats were no longer as profitable as in earlier years. For example, a flat rented in 1931 for 700 Lithuanian litas was available one year later for 450 litas $^{6}$.

6 Surankiotos pastabos [Collected notes], "Lietuvos aidas" S3urankiotos past 
Municipal authorities even considered imposing a special fee on flats left vacant for an excessive period of time.

The decline in overall construction has also contributed to a rise in competitio that helped solidify expectations for higher construction quality and new aesthetic standards. Indeed, the economic crisis per od saw the completion of such model examples of modernism as the home of Elena Baroniene and Petras Vysockis (finished in 1933, fig. 7), the multi-unit building in whic Kazimieras Škemma resided (also 1933), the residential building of Aleksandra Iliniene resict (hinished in notable public buldings were also built up during the heat of the economic crisis: office of "Pienocentras" company (finished in 1932, fig. 9), Kaunas County office and Lithuanian State Security Department (finished in 1933, fig. 10), Palace of Physical Culture (finished in 1934, fig. 11) and others.

$$
\text { By 1937, Lithuania had already begun }
$$
recovering from the economic downturn. Historical archives contain a rather amusin account of the period, written by a participant of a Baltic road conference held in Kaunas in that same year: "Visitors from Latvia and Estonia were extremely surprised by the amount of construction they saw when they toured the city and its environs. They admitted that no such level of construction was underway in Latvia or Estonia this year. To them, it seemed as if Lithuania was rebuilding after some horrible catastrohe - a war or an earthquake Our engineers phe-awar an earth showing them and all of what they were seeing was being done after a terrible misfortune - an economic crisis that Lithuania now felt it had overcome"

The recovery in construction was evidenced by both a rise in the number of

7 Radio laidu medžiaga. Paskaita apie Kauno statybas [Radio wiring material. Lecture on the construction building projects and the rapid transformation of the urban landscape. Vytautas the 12). Chamber of Commerce, Industry and Crest Crafts was finshed in 1938 (fig.13), Chamb Cf Labour - in 1939 (fig. 14), State Saving Bank - in 1940, etc. Finally the Vytautas Magnus University Clinics - one of the biggest architectural complexes of that time, started to operate in 1939 (fig. 15). Rapid modernization was particularly evident in the central part of the city, where old wooden homes were forced to yield to modern, multi-storey buildings. Though interiwo the were still full of ramshackle sheds and ag ing wooden homes, wooden houses along the streets were demolished without a second thought. The intense pace of construction was only slightly held back by a shortage of construction materials and instability of the country's political situation.

\section{DIVERSITY OF INFLUENCES AND}

\section{STYLISTIC APPROACHES}

Despite the fact that Lithuania's independence lasted only two decades, this short period marked a very rapid change not only in the development of the city, but also in transformations of the aesthetical preferences in architecture. The first decade of independence was dominated by various interpretations of historicism. Neobaroque was treated as a local style due to Vilnius. Representative character of the Bank of Lithuania (fig. 16) or Ministry of ustice was achieved thanks to the use of classical language of architecture. Meanwhile, the search for new architectural ideas was shaped by a combination of two main motifs: modernization and national identity.

$$
\text { Political situation of the country had }
$$
an impact not only on the status of the city, but also on the aesthetical preferences for architectural environment. Among the distinctive ideological motivations there was a search for a nationalidentity expressed as cerced "nation style". The ide was obviso-called "natinalstyle". The idea was obviously interconnected with the political goals of the state - to strengthen its role in the cultural field in such a way as to construct a strong national state. Architecture had a special mission - to create a distinctive urban environment and to demonstrate an architectural expression which was dissimilar to that of the tsarist Russian legacy. Such an objective for the "national style" can be debribed in " scribed in words of Karols Reisonas, one of the most famous Lithuanian architects of that time, who stated. "we, Lithuanians, have to show high creativity, and to make our architecture interesting in a global scale; to prove that we live not in vain, not in vain occupy the part of the globe"8.

The dispute between conservative nationalism and modern architecture was often complemented by rhetorics resembling folk traditions. The decisive role in e decisive role in this discussion was played by folk art researchers and supporters, who had no doubt that the most excellent basis for a "national style" of architecture should stem from folk art in its broad sense. Text emphasizing a special Lithuanian "art feeling" and an inclination toward ornamentation were the main foci of this point of view. As the famous Lithuanian artist Adomas Varnas claimed: "the decorative wooden cross, as it was used in our folk kind of pyramid of our ow". As a result, most of the examples of a "national style" in professional architecture were treated as a kind of historicism in which traditional

8 K. Reisonas, Naujos idejos architektüroje [New ideas in architecture], "Savivaldybè" 1933, no 9, p. 35 . 9. A. Varnas, Lietuviụ kryžiai [Lithuanian crosses], "Baras"
1925, no 5, p. 81 . stylistic elements were replaced by decorative motifs of folk art (fig. 17).

$$
\text { In some cases, architectural aspira- }
$$

tions could be placed somewhere close to

those sim

the tectural traditions of Lithu the local archplayed an important role, indicating possible sources for national architectural identity. "Why do we have to seek examples somewhere abroad? Isn't it better to explore the Samogitian [north-western region of

Lithuania - V. P.] farmsteads instead, and to adapt them to new progressive and hygienic requirements, while preserving their

style?" important journals on urban and architectural issues. Probably the best example of this approach is a combination of clear surfaces and geometric volumes of modernis with a tradition of pitched roofs (fig. 7, 18).

Although the attempts to search for the Lithuanian spirit in professional masonry construction are not a common phenomenon, various decorations (not only in the national-style) that can now be linked to Art Déco, remain an important piece of Kaunas' architecture during the entire period of independence. Even in the late 1930s, a new generation architect, Feliksas Bielinskis, was convinced that "the ornament must, in its form, interpret the meaning and designation of the entire building" ${ }^{11}$. Kaunas central post office could be a good illustration of such aspiration to integrate modernity and local character expressed in ornamentation. Window frames imitating wooden carving, floor tiling designed to resemble ornaments on traditional textiles and interior ornament based on folk art (fig. 19) were combined with such expressive

\footnotetext{
10 Kaimu ir miesteliu pagražinimas [The embellishment of
villages and townships], "Savivaldybe" 1938, no 4, p. 98 . F. Bielinskis, Architektüros esmè [On Essence of
} 
signs of modernism as wide strip windows and flat roof.

Some early political aspirations of the new state of Lithuania to build as many "cheap, accurate, hygienic and fireproof dwellings" ${ }^{\prime 1_{2}}$ as possible reflect tendencies of Modern Movement. However, keywords of modernism in Lithuanian architectural theory and practice became dominant in the 1930 s, when the younger generation of Lithuanian architects began to return from their studies at European universities (Rome, Prague, Berlin, etc.) and brought with them new ideas of how contemporary capital should look. Newspapers and journals bega should look. News con to explain the asthetics of modernism, and local officials, after their visits to Germany, England, and Sweden, brought back descriptions of construction of schools, social housing and other civic infrastructure. Vladas Švipas, a student of the Bauhaus in 1927, is one of the first people to write: "our cities have many historical documents that do not touch our minds anymore because they are touch our tinds any dec are past ther time. Therefore, architects who still design using historical styles, have to take responsibility for their preference. These houses are mummies, corpses which will stand publicly for centuries ${ }^{{ }^{1_{13}} \text {. }}$.

$$
\text { Such theoretical assumptions of the }
$$

1930 s were transformed into world-re-

nance of ribbon windows, flat roofs, geometric volumes and planes. The representative office of "Pienocentras" (a manufacturer of milk products, one of the richest com milk products, one of in Lithuania at that time)-could be a good example of the emergence of modernist ideas in all areas. At the 1937 Paris Internation Exposition, which was dedicated to Art and Technology in modern life, the building won

12 Lietuvos atstatymo komisariato aplinkrašstis [Circular of the Lithuanian Reconstruction Commissariat], 1923 m. LCVA f. 377, ap. 8, b. 4, p. 64

$13 \mathrm{~V}$. Švipas, Architektūros reikalu [On matters of a prize for its architectural design, and became one of the symbols of modern ideas in ithuanian architecture of the time (fig. 9 ). Another symbolical illustration is the Resurrection Church (fig. 20). After a long (a) Reisonas began to develop his grandiloquen building. It was completed and started to serve as a church in 2004. Rising above the slope horizon surrounding the city the church brings to mind the concept of Stadtkrone - the City Crown - formulated by a renowned German architect, Bruno Taut.

Private houses are probably the most prous examples of the Kaun school of Many imp the Kaunas school of uch ar in Bronius Elsbergas (fig. 7) Jokūbas Peras (fig. 21), Jonas Kriščiukaitis (fig. 22) and others stand out with original and expressive forms, which, without a doubt, represent the best achievements of Lithuanian interwar modernism. A new concept for housing was first presented in the Lithuanian press by Vlados Švipas, who received eduction Ba which hes which he begun to write in $1927^{14}$, evolve into a separate publication based on the principles of the Bauhaus. It was publishe in 1933 and entitled Miesto gyvenamieji namai (Urban Residential Homes) ${ }^{\text {s. }}$

The modernization of the housing environment was accompanied by a considerably broad theoretical discourse, with the principles of modern housing being widely discussed both in print and by general population, with an emphasis on efficiency and rationalism. Modern buildings "must set an xample for the economization of space, labour and money. A home's floor space must

14 Ibidem, p. 329-334; V. Švipas, Butas egzistencijos minimumui [Apartment for existence minimum],
"Naujas žodis" 1929, no 20-21, p. 10-11 and others. V. Švipas, Miesto gyvenamieji namai [Urban Residentia 15 V. Švipas, Miesto gyven
Homes], Kaunas 1933 . be used as efficiently as the one on a ship"16, an anonymous commentator wrote in a publication for construction specialists. The aesthetic aspect was discussed as well, ing authortative exame ing authoritative examples and practices seen in the great cities of Europe, most oft Berlin. One reader and enthusiast of modernism, writing under Viator (Traveller) pen name, wrote: "The construction style alone is captivating. Straight lines create an extraordinary beauty with their simplicity ${ }^{{ }{ }_{17} \text {. }}$

However, when trying to define the

characteristics of Kaunas modernism, one has to deal with a phenomenon much more diverse than simplicity of Modern

Movement. Despite some interesting examples of architecture based on innovative

technologies, such as reinforced concrete or glass (fig. 23), the modernist principles of existential minimalism and standardisation were not adopted in full scale in Kaunas.

\section{Aspirations for modernisation have been,}

in many cases, overwhelmed by the con-

\section{servative thoughts. For example}

Landsbergis-Žemkalnis, who used rather innovative technological solutions in the

Palace of Physical Education (fig. 11), explain that from aesthetical point of view he sought "to combine two things and two forms into one building: the classics, the first great pioneer of physical culture (Greece),

with our times" ${ }^{\prime \prime}$. Such a monumental classical rhythm of modern forms describes many buildings of Kaunas built in the 1930s (fig. 13).

\section{CONCLUSIONS}

To sum up, architecture of the

interwar period in Lithuania, and especially

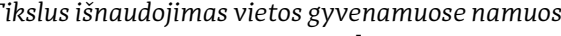 [Exact use of space
1932 , no 2-3, p. 12 .}

17 Viator, Pasivaikščiojimas po Naujaji Berlyna [Walkin around New Berlin], “Bangos” 1932, no 45, p. 1183-1184

$18 \mathrm{~V}$. Landsbergis, Fiziško auklèjimo rūmai [House of physical Education], "Fiziškas auklèjimas" 1931, no 2, in Kaunas is an interesting mixture of the Modern Movement, interpretations of socalled "national style", and of local architectural taste. Although Kauna was built with a hope of restoring the historic capital of a hope of restoring the historic capital of Vinius, the optimistic residents created a contemporary, modern and stylistically diverse city with high-quality, durable buildings. One of the most important goals of the interwar architecture - to create an original formula of Lithuanian architecture, was completely implemented through modernisation of the city instead of naive folk art imitations in professional architecture. Over twenty yers Kaunas has became Over twenty years Kaunas has beame an excellent example of petit modernisme: the city maintains a scale that is not overpowering people, has buildings of distinctive architectural quality, and the established genius loci of the central part is still preserved.

\section{KAUNAS OF 1919-1939:}

CAPITAL BUIL

\section{BY ITS CITIZENS}

W latach 1919-1939, wskutek sytuacji politycznej Kowno zyskało status tymczasowej stolicy Litwy. Te dwie dekady, w czasi których miasto było centrum wielu ważkich wydarzeń politycznych, ekonomicznych i kulturalnych, znacznie przyczyniły się do stworzenia tożsamości Kowna. W tym okresie miał miejsce boom architektoniczny, który zaowocował pojawieniem się wyjątkowej grupy budynków, charakteryzujacych się unikalnym połączeniem rozmaitych wplyuńwi wow interpretacji modernizmu oraz narodowego romantyzmu. Niniejszy artykuł
przedstawia historyczny przegląd kulturalprzedstawia historyczny przegląd kultural-
nych i ekonomicznych okoliczności, które wpłynęły na rozwój budownictwa w Kownie w okresie dwudziestolecia międzywojennego. 